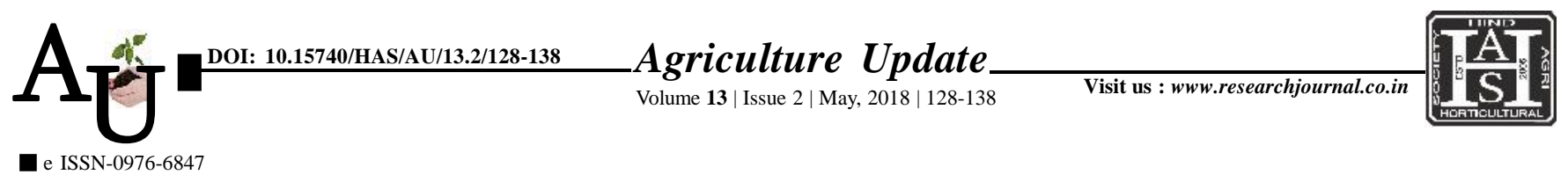

\title{
Rеsearch Article: Screening of cotton genotypes against salinity stress based on its physiological and biochemical responses
}

\author{
H.R. Ramani, V.K. Vekariya, D.H. Patel and B.G. Solanki
}

Article Chronicle: Received :

20.02.2018;

Revised :

17.03.2018;

Accepted :

03.04.2018

KEY Words:

Salinity tolerance, Cotton, Relative water content, Membrane stability

Author for correspondence :

\section{H.R. Ramani}

Main Cotton Research

Station (N.A.U.),

Athwafarm, Surat

(Gujarat) India

Email:hiteshramani2007@

gmail.com

See end of the article for

authors' affiliations
SUMMARY : The experiment was carried to screened cotton genotypes for salinity tolerance in the kharif season of 2016-17. Eleven cotton genotypes were selected and grown upto squaring stage in different soil ratio of normal soil and saline soil after that leaf samples were collected and all the biochemical parameters were recorded for screening of cotton genotypes for salinity tolerance. Genotypes GISV-218 and G. Cot-16 showed highest relative water content in all the treatment. Genotypes G.Cot-16, GISV-218 and BC-68-2 showed highest membrane stability in normal soil condition where genotypes G. Cot -16, GISV-218 and 76-1H-20 were showed highest membrane stability $(78.79 \%, 78.29 \%$ and $74.70 \%$, respectively) in saline soil. Range of proline content was ( 0.23 to $0.56 \mathrm{mg} / \mathrm{g}$ of tissue) in normal soil condition and it was ( 0.75 to $1.35 \mathrm{mg} / \mathrm{g}$ of tissue) in saline soil condition. Highest glycine betaine content was found in G. Cot-16, GISV-218 and BC-68-2 in saline soil while lowest glycine betaine was found in GSHV-01/1338 and G.COT-10 in saline soil. Highest lipid peroxidation were showed by cotton genotypes Surat Dwarf and G. Cot-100 followed by G. Cot-10 and 76-1H-20. Highest surface wax was found in genotypes GISV-218, G.Cot-16 and BC-68-2. Highest total phenol content was found in GISV-218, G. Cot-16 and BC-68-2. Lowest total phenol content was found in G.Cot-10 and G.Cot-100. In all genotypes, total phenol content was increased as salinity increased. Highest peroxidise activity was found in GISV-218, G.Cot-16 and American nectriless while highest catalase activity was found in GISV-218 and Surat Dwarf in ratio of 1:2 (Normal soil: Saline soil). Lowest activity was found in LRA5166 and BC-68-2. Highest Superoxide dismutase activity was found in GISV-218 and Surat Dwarf in ratio of 1:2 (Normal soil: Saline soil). Lowest Na/K ratio was found in GISV-218 and G. Cot-16 in root while lowest $\mathrm{Na} / \mathrm{K}$ ratio was found in GISV-218, G. Cot-16 and American nectriless in shoot. Cotton genotypes GISV-218 and G.Cot-16 showed better performance in all the treatments so it might be salinity tolerance while G. Cot-100 and G. Cot-10 might be susceptible to salinity and rest of the genotypes might be moderately tolerant to salinity.

How to cite this article : Ramani, H.R., Vekariya, V.K., Patel, D.H. and Solanki, B.G. (2018). Screening of cotton genotypes against salinity stress based on its physiological and biochemical responses. Agric. Update, 13(2): 128-138; DOI : 10.15740/HAS/AU/13.2/128-138. Copyright@ 2018: Hind Agri-Horticultural Society. 